\title{
Quality of Oilseed Brassica as Influenced by Planting Techniques and Genotypes
}

\author{
Sumit Chaudhary ${ }^{1}$, Alankar Singh ${ }^{1 *}$, Pallavi $^{2}$, Anil Shukla ${ }^{3}$, \\ Chandrabhushan $^{3}$, M.S. Negi ${ }^{3}$, Anil Nath ${ }^{4}$ and B.S. Mahapatra ${ }^{3}$ \\ ${ }^{1}$ College of Forestry, VCSGUUHF, Ranichauri, Uttarakhand, India \\ ${ }^{2}$ Department of Agriculture, Dolphin (PG) Institute of Biomedical \& Natural Sciences, \\ Dehradun, India \\ ${ }^{3}$ GBPUAT, Pantnagar, Uttarakhand, India \\ ${ }^{4}$ Management Trainee (Production), NSC Ltd, Uttar Pradesh, India \\ *Corresponding author
}

\section{A B S T R A C T}

\section{Keywords}

Oilseed Brassica, Planting Techniques and Genotypes

Article Info

Accepted:

15 January 2019

Available Online:

10 February 2019
A field experiment was conducted at GBPUAT, Pantnagar during rabi season of 2014-15 to assess the influence of planting techniques on oil and protein quality of Brassica genotypes. The experiment was designed and laid out in split plot arrangement taking planting method in main-plots and Brassica species in subplots with 3 replications. The planting methods significantly influenced the oil content (\%), oil yield and protein yield. Conventionally sown crop resulted in higher oil content (\%), however, oil yield was significantly higher in transplanted crop. Among the three genotyopes, Pant Shweta resulted in significantly higher oil content over the other two genotypes.

\section{Introduction}

Plant density is one of the most effective agronomic factors for determining the yield which is individually affected by cultivar and climatic conditions as well as production system (Zandi et al., 2011). This statement holds true for most of the production system involved in crop production. Rapeseed \& mustard belonging to family Brassicaceae is one of the most important oilseed crop of
India which caters the oil requirements of large population in the country. The productivity of Brassica $\mathrm{Sp}$. is highly dependent on various biotic and abiotic stresses which also influence the area and production of oilseed Brassica. To reduce losses from such kind of stresses scientist and researchers are continuously in developing new techniques so that maximum output can be harvested from minimum inputs in an ecofriendly and sustainable manner. Delay in 
sowing time is one of the major causes that negatively influence the productivity of rapeseed and mustard. This problem can be overcome by adopting the transplanting technique in rapeseed and mustard crop. Khan et al., (1990) also showed that transplanting could be a better option under late sowing in barley and triticale crop. However the success of transplanting is area specific and need to be studied in a detailed manner.

\section{Materials and Methods}

A field experiment was conducted during the rabi season of 2014-15 at N. E. Borlaug Crop Research Centre of GB Pant University of Agriculture \& Technology, Pantnagar $\left(29^{\circ}\right.$ $\mathrm{N}^{\prime}, 79^{\circ} 29 \mathrm{E}$ ' and $243.83 \mathrm{~m}$ amsl) to assess the effect of planting methods and genotypes on the oil and protein quality of rapeseedmustard. The soil of the experimental site was silty clay loam with $p \mathrm{H} \mathrm{7.2,} \mathrm{organic} \mathrm{carbon}$ $0.81 \%$; and $261,21.3$ and $231 \mathrm{~kg} / \mathrm{ha}$ of $\mathrm{N}$, $\mathrm{P} 2 \mathrm{O} 5$ and $\mathrm{K} 2 \mathrm{O}$, respectively. The experiment consisted of 12treatments, having four planting techniques $(90 \mathrm{~cm} \times 60 \mathrm{~cm}$ transplanting, $60 \mathrm{~cm}$ and $60 \mathrm{~cm}$ transplanting, $75 \mathrm{~cm}$ and $75 \mathrm{~cm}$ transplanting, and the conventional planting) in main-plots and 3 Brassica genotypes [Brassica juncea cv.'Kranti', B. carinata cv. 'RP 09' and $B$. rapa ssp. yellow sarson cv. 'Pant Shweta'] in sub-plots was laid out in split-plot design with 3 replication. Seedlings were raised out in black polythene bag and were transplanted manually at 15 day's stage at required spacing. Crop was fertilized uniformly with $120: 40: 20 \mathrm{~kg} / \mathrm{ha}$ of $\mathrm{N}, \mathrm{P}$ and $\mathrm{K}$, respectively. Half of the nitrogen along with full amount of phosphorous and potassium was applied at the time of sowing as basal. The remaining nitrogen was top dressed in 2 equal splits. The oil content in seed was determined by Soxhlet extraction method taking petroleum ether as a solvent. The oil content was reported on per cent basis. The oil yield was computed by multiplying the oil content value with seed yield as per treatment and the oil data were presented in $\mathrm{kg} \mathrm{ha}^{-1}$. Protein content in seed was determined by multiplying nitrogen content in seed (percentage) by a factor 6.25. The crude protein (Protein yield) was calculated by multiplying seed yield with protein content in seeds i.e. $\%$ Protein $=\% \mathrm{~N}$ (Total $\mathrm{N}$ in seeds) 6.25 .

\section{Results and Discussion}

The data related to oil content, oil yield, protein content and protein yield is presented in Table 1. Oil content was significantly influenced by different planting geometries and genotypes. Significantly higher oil content was observed in conventionally planted over all the other transplanting geometries. However, no significant difference was observed among the various transplanting geometries in terms of oil content. Among the different Brassica genotypes, Pant Shweta (B. rapa) produced significantly higher oil content over the other two genotypes. This difference may be due to varietal effect. Shukla and Kumar (1992) at Pantnagar also observed that mustard variety Vardan had the highest oil content in comparison with Krishna, Kranti, Rohini, Varuna, and Pusa Bold. The oil yield was influenced significantly by different planting geometries and genotypes, and remained maximum in the transplanted crop. Transplanting at $60 \times 60 \mathrm{~cm}$ significantly produced higher oil yield over the other planting geometries. Transplanting at 90x60 and $75 \times 75 \mathrm{~cm}$ remained on a par but significantly superior over the conventional sown crop. The more oil yield per hectare in transplanted crop was a resultant of the seed yield and the oil content, and both of these components were influenced by plant growth and yield attributing characters. The reduction in oil yield and seed yield under conventional planting was recorded due to less time and 
space for growth and development of crop. Among the various genotypes, RP-09 produced the highest oil yield being significantly superior over the other two genotypes. In spite of having the maximum oil content, Pant Shweta could not compete with the other two genotypes in terms of oil yield owing to its inferiority in seed yield.

Table.1 Quality parameters viz. Oil content (\%), protein content $(\%)$, oil yield $\left(\mathrm{kg} \mathrm{ha}^{-1}\right)$ and protein yield $\left(\mathrm{kg} \mathrm{ha}^{-1}\right)$ of oilseed Brassica as influenced by transplanting geometry

\begin{tabular}{|c|c|c|c|c|}
\hline Treatments & $\begin{array}{l}\text { Oil content } \\
(\%)\end{array}$ & $\begin{array}{l}\text { Protein } \\
\text { content }(\%)\end{array}$ & $\begin{array}{l}\text { Oil yield (kg } \\
\mathrm{ha}^{-1} \text { ) }\end{array}$ & $\begin{array}{l}\text { Protein yield } \\
\left(\mathrm{kg} \mathrm{ha}^{-1}\right)\end{array}$ \\
\hline \multicolumn{5}{|l|}{ Planting geometry $(\mathrm{cm})$} \\
\hline 90x60 Transplanting & 40.0 & 19.9 & 640.7 & 316.2 \\
\hline 60x60 Transplanting & 40.4 & 19.8 & 976.1 & 475.6 \\
\hline 75x75 Transplanting & 40.2 & 19.9 & 643.1 & 316.4 \\
\hline Conventional & 41.0 & 19.6 & 483.3 & 231.7 \\
\hline SEm \pm & 0.18 & 0.08 & 17.4 & 7.34 \\
\hline $\mathrm{CD}(\mathrm{P}=0.05)$ & 0.6 & NS & 60.2 & 25.4 \\
\hline \multicolumn{5}{|l|}{ Genotypes } \\
\hline B. juncea (Kranti) & 38.7 & 19.9 & 639.2 & 328.5 \\
\hline B. carinata (RP-09) & 40.7 & 19.1 & 914.1 & 429.3 \\
\hline B. rapa (Pant Shweta) & 41.7 & 20.4 & 504.1 & 247.2 \\
\hline SEm \pm & 0.19 & 0.18 & 13.5 & 6.52 \\
\hline $\mathrm{CD}(\mathrm{P}=0.05)$ & 0.6 & 0.5 & 40.6 & 19.5 \\
\hline
\end{tabular}

The higher oil yield in case of RP-09 was due to the fact that RP-09 produced more seed yield, increasing the oil yield thereby. The varietal differences in oil yield have also been reported by Kumar et al., (1996) and Singh and Singh (1998). Different planting geometries did not differ significantly for protein content in seeds Protein content in seed was higher in transplanted over the conventionally planted crop. Among the different transplanting geometries maximum protein content and yield was observed in $60 \times 60 \mathrm{~cm}$ transplanting. Pant Shweta remained significantly superior over the other two genotypes in case of protein content. Protein yield was significantly influenced by the planting geometries and genotypes. Among the four planting geometry, transplanting at $60 \times 60$ produced significantly higher protein yield over the other geometries. Among the various genotypes, RP-09 produced the highest protein yield being significantly superior over rest of the genotypes which is be due to higher seed yield. Significantly lower protein yield was observed in case of yellow sarson variety Pant Shweta. Gangwar and Kumar (1986) reported in toria that higher protein content in seed was recorded at lower levels on plant density. With the results obtained during the course of investigation it could be concluded that the transplanting of Brassica carinata (RP-09) at 60x60 cm could be beneficial in the tarai region of Uttarakhand. As the investigation was carried out for one crop season only, it needs to be repeated for at least one more season for reconfirmation of the results.

\section{References}

Gangwar, K.S. and Kumar, A. 1986. Nitrogen fertilization and plant density levels in relation to yield, its attributes and 
quality of toria. J. Oilseeds Res. 3(2): 151-157.

Khan, A.Z.; Shah, P. and Khan, S. 1990. Yield and yield components of wheat, barley and triticale transplanted and direct seeded on different dates. Pakistan J. Agri. Res. 11: 1.

Kumar, Anil; Singh, D.P. and Yadav, S.K. 1996. Influence of nitrogen on yield oil content of Brassica genotypes. Agric. Sci. Dig. Karnal. 16(2): 90-92.

Shukla, A. and Kumar, A. 1994. Effect of some Indian mustard varieties and nitrogen levels on growth, yield and quality. Ann. Agric. Res. 15(1): 76-80.

Singh, R.P. and Singh, Y. 1998. Performance of rainfed Indian mustard (B. juncea) varieties at varying levels of nitrogen. Indian J. Agron. 43(4): 709-712.

Zandi, P., Shirani-rad, A.H. and Bazrkarkhatibani, L. 2011. Agronomic study of fenugreek grown under different inrow spacing and nitrogen levels in a paddy field of Iran. Am-Euras. $J$. Agric. Environ. Sci. 10: 544-550.

\section{How to cite this article:}

Sumit Chaudhary, Alankar Singh, Pallavi, Anil Shukla, Chandrabhushan, M.S. Negi, Anil Nath, and Mahapatra, B.S. 2019. Quality of Oilseed Brassica as Influenced by Planting Techniques and Genotypes. Int.J.Curr.Microbiol.App.Sci. 8(02): 1963-1966. doi: https://doi.org/10.20546/ijcmas.2019.802.229 